\title{
Inclusive Education in Russia: Legal Development Prospects
}

\author{
Victor Baranov \\ Financial University under the \\ Government of the Russian \\ Federation \\ Moscow, Russia doctor of legal \\ sciences, deputy dean of the Law \\ faculty for science research and \\ international cooperation, \\ professor of the Department of \\ legal regulation of economic \\ activities of the Financial \\ University under the Government \\ of the Russian Federation. \\ VBaranov@,fa.ru
}

\author{
Oksana Petyukova Financial \\ University under the Government \\ of the Russian Federation \\ Moscow, Russia \\ doctor of legal sciences, deputy \\ dean of the Law faculty for \\ science research and international \\ cooperation, professor of the \\ Department of legal regulation of \\ economic activities of the \\ Financial University under the \\ Government of the Russian \\ Federation_OPetyukova@,fa.ru \\ Alena Prizhennikova Financial \\ University under the Government \\ of the Russian Federation \\ Moscow, Russia \\ candidate of legal sciences, \\ associate professor, associate \\ professor of the Department of \\ legal regulation of economic \\ activities the Financial University \\ under the Government of the \\ Russian Federation \\ APrizhennikova@,fa.ru
}

\author{
Natalia Vilskaya Financial \\ University under the Government \\ of the Russian Federation \\ Moscow, Russia \\ Senior lecturer of the \\ Department of legal regulation of \\ economic activities the Financial \\ University under the Government \\ of the Russian Federation \\ NVvilskaya@fa.ru
}

\begin{abstract}
In the article the questions of legal nature related to the organization of inclusive education for disabled persons and persons with disabilities on the basis of the implementation of the UN Convention on the rights of persons with disabilities. The analysis of the changes to article 71 of the Federal law "On education in Russian Federation" and the letter of the Ministry of education of Russia from 15.06.2017. The analysis of the Russian and foreign experience and based on the findings and formulates proposals for improving the legal foundations of inclusive education in the Russian Federation.
\end{abstract}

Keywords- disabled person, psycho-medico-social commission of medical social examination, the individual program of rehabilitation or habilitation, special conditions for receiving education, educational institutions, individual educational plan, individual training schedule, adaptivnye disciplines (modules).

\section{INTRODUCTION}

The main legislative act of the state and sectoral legislation do not provide for disabled persons [1] and individuals with disabilities [2] any obstacles to higher education (article 43 of the Constitution of the Russian Federation), therefore it is necessary to create special conditions for persons with disabilities.

The UN Convention on the rights of persons with disabilities of 2006[3] defined the right of persons with disabilities to education while maintaining their individuality, personal independence and human dignity. Under article 24 of the Convention, States parties have the obligation to ensure inclusive education at all levels. The issues of inclusiveness in education are reflected in many international acts[4].

The concept of " inclusive education "is contained in the Federal law of December 29, 2012 N 273-FZ" on education in the Russian Federation which means ensuring equal access to education for all students, taking into account the diversity of special educational needs and individual opportunities.

\section{RELEVANT THEORETICAL STUDIES}

The concepts of "disabled person" and "restriction of life" are introduced into the legislation of the Russian Federation by article 1 of the Federal law of 24 November 1995 № 181 FZ "on social protection of disabled people in the Russian Federation".

Recognition of a person as a disabled person is carried out by Federal medical and social examination institutions subordinated to the Ministry of labor of Russia. The order and conditions of recognition of the person as the disabled person are defined by the order of the Government of the Russian Federation[5], and the order of the Ministry of labor of Russia[6] approved criteria which have to be used at implementation of medical and social examination.

Currently in Russia data about disabled-students, enrolled on professional educational programs on period 01.02.2018 the next (data set only on public (municipal) organizations)[7].

Beginning of the academic year 2013/2014: accepted students-5194; number of students-16779; graduates-2712.

Beginning of the academic year 2014/2015: students accepted-5179; number of students-16768; graduates - 2561.

Beginning of the academic year 2015/2016: accepted students-5966; number of students-18043; graduates-4120.

Beginning of the academic year 2016/2017: accepted students-6087; number of students-19538; graduates - 3139 .

Beginning of the academic year 2017/2018: accepted students-6881; number of students-21757; graduates-3214. 
It should be noted that, in General, higher education institutions pay attention to the creation of conditions for the physical accessibility of attendance by persons with disabilities and persons with disabilities (ramps are created, special lifting devices are purchased)[8]. At the same time, people who have other health problems, who need completely different measures relating to the forms, methods and material and technical support of the educational process, requiring certain labor, educational and methodical nature and material costs to create appropriate learning conditions, remain without attention[9]. Thus, for example, education of children who are blind, deaf or deaf-blind should be carried out using the most appropriate languages, methods and ways of communication.

\section{LEGAL PROBLEMS OF INCLUSIVE EDUCATION}

The question of appropriate learning (special learning) conditions in education legislation remains open, although the content of this part is important. The solution of this issue will eliminate the problems of implementation of inclusive education in practice. Thus, in Russia the concept of inclusiveness does not correspond to the full content of the norm reflected in article 24 of the Convention on the rights of persons with disabilities, namely, the full development of human potential, the development of personality, talents and creativity of persons with disabilities, effective participation in society.

Foreign experience shows that students with disabilities are partially (gradually) included in the educational process: communication in the learning process, communication at various events, communication in the framework of additional education[10]. The main goal is to increase social contacts[11]. For example, in the US, the education for persons with disabilities Act of 1997. (Individuals with Disabilities Education Act) contains the rule that disabled persons and persons with disabilities can be trained in the first half of the day in the usual mode provided by the program of the University, and the rest of the day - to study on a special rehabilitation program with continuous support from various specialists.

The authors of the article consider it interesting to include in the variable part of the educational program specialized adaptive disciplines (modules)[12], based on the requirements of part 1 of article 79 of the Federal law of 29.12.2012 № 273FZ "on education in the Russian Federation". Introduction of specialized adaptation disciplines (modules) in the basic educational programs is intended for additional individualized correction of violations of educational and communication skills, professional and social adaptation at the stage of higher education. This may be the discipline of social and humanitarian purposes, professionalizing profile, as well as for the correction of communication skills, including through the development of special information and compensatory technology of reception and transmission of educational information[13]. In educational process it is recommended the use of socially-active and reflective learning methods, technologies of socio-cultural rehabilitation, with the aim of assisting in the establishment of full-fledged interpersonal relationships with other students, creating a comfortable psychological climate in the student group.

Not every higher education institution has such trained staff and this is due to a number of reasons[14]. One of them is that when admitting applicants from among the disabled and persons with disabilities, there is no information about what conditions of education are necessary for these persons. In this regard, the higher educational institution hypothetically must create all conditions in advance, as it is not allowed to refuse to accept this category of students within the allocated quota[15]. Therefore, it is necessary to plan in advance educational and methodical work and acquisition of technical means[16].

In accordance with Russian legislation, all disabled persons are admitted to higher education institutions without any restrictions. In the letter of the Ministry of education of Russia[17] it is explained that, according to the changes made by the Federal law N 93-FZ, the disabled person arriving on training within the special quota or wishing to use the preferential right of transfer represents according to the subparagraph 12 or 13 of point 68 of the Order the certificate of disability. It does not require a document containing the conclusion of the Federal institution of medical and social expertise on the absence of contraindications for training in the relevant organizations, so the disabled person should not submit an individual rehabilitation program, which was previously submitted in accordance with subparagraph 6 of paragraph 68 of the Order. Thus, there are the following problems: first, how to take into account the peculiarities of psychophysical development, individual health opportunities of such students; secondly, how to implement the training of persons with stage 3 restrictions, providing the ability to learn only basic skills and skills (professional, social, cultural, everyday), including the rules of execution only elementary purposeful actions in a familiar everyday context or the limitations of capacity for such training in connection with the existing significantly severe disturbances of body functions, defined based on the conclusion of psychological-medicalpedagogical Commission; third,is it possible to implement an individual approach to each disabled student.

To resolve problematic issues and inclusion in vocational education should be monitored to ensure availability in establishments of professional education conditions for professional education of disabled persons and persons with disabilities[18]; approve the relevant requirements to organization of educational process for training of disabled persons and persons with disabilities in vocational training establishments, including equipment of educational process[19]; C) development and implementation of special programs of vocational education adapted for training of disabled persons and persons with disabilities, etc.[20]

\section{CONCLUSIONS AND PROPOSALS}

According to the results of the study, the following conclusions can be drawn: 1) the implementation and development of inclusive education in Russia is carried out by creating special learning conditions for children with 
disabilities; 2) in the educational space, on the basis of the Russian legislation, for children with disabilities, the model based on the concept of adaptation to the educational system; 3) to create special conditions for students with disabilities to receive education, it is necessary to implement the requirement of paragraph 6 of article 79 of the Federal law "on education in the Russian Federation"; 4) it is necessary to solve the issue of specialization of higher education institutions, special conditions in them for working with students with certain types of diseases; 5) to train teachers to develop practical skills and skills of teaching such students; 6 ) to prepare an effective educational and methodical base for this and will allow to organize the training of students with disabilities in separate groups and individual organizations; 7) medical and social expertise of the issue of the ability of persons with disabilities and the disabled to learn, which should be reflected in the individual program of rehabilitation[21]; 8) it is necessary to develop optimal educational routes, and the Ministry of education, together with the Ministry of labor to develop a regulatory and methodological framework for the organization of the educational process and teaching methods, taking into account the nature of the disease; 9) the Ministry of education and science should provide for specialization of higher education institutions, in relation to the nature of diseases and on this basis to determine quotas[2] for admission of persons with disabilities; 10) educational organizations need to adopt local regulations governing the admission of such students.

Thus, in order to create a "truly" inclusive model of education in Russia, real changes in thinking and culture of education are needed, and the paradigm of exclusive education needs to be changed to inclusive

\section{REFERENCES}

[1] Federal law No. 181-FZ of 24.11.1995 "On social protection of disabled persons in the Russian Federation".

[2] 2.Federal law of 29.12.2012 No. 273-FZ "On education in the Russian Federation".

[3] 3.Federal law of $03.05 .2012 \mathrm{~N}$ 46-FZ "On ratification of the Convention on the rights of persons with disabilities" // LRS «Consultant Plus».

[4] 4.The Salamanca Declaration on principles, policies and practices in the education of persons with special needs 1994 //LRS «Consultant Plus».

[5] 5.Resolution of the Government of the Russian Federation of 20.02.2006 No. 95 «On the procedure and conditions for recognition of a person as disabled».

[6] 6.Order of the Ministry of labor of Russia No. 1024n of 17.12.2015 " On classifications and criteria used in the implementation of medical and social examination of citizens by Federal state institutions of medical and social examination ".

[7] 7.Federal state statistics service //URL: //http://www.gks.ru/wps/wcm/connect/rosstat_main/rosstat/ru/statistics/pop ulation/disabilities.

[8] 8.Jennifer A. Kurth, Alison L. Zagona, «Involvement and participation of students with severe disabilities in SWPBIS». The Journal of Special Education, vol. 52, 2018, pp.234-246.

[9] 9.Ane Qvortrup, Lars Qvortrup, «Inclusion: Dimensions of inclusion in education». International Journal of Inclusive Education, vol. 21, 2017, pp. 803-817.

[10] 10.Maria Helena Martins, Maria Leonor Borges,Teresa Gonçalves, «Attitudes towards inclusion in higher education in a Portuguese university». International Journal of Inclusive Education, vol. 21, 2017, pp. 527-542.
[11] 11.Rogers George. Revolution of Inclusion. Research Bulletin. Phi Delta Kappa. Center for evaluation, development and research. 1993. No. 11. Claim 2. P.5.

[12] 12.Methodical recommendations on the organization of educational process for training of disabled persons and persons with disabilities in educational institutions of higher education, including the equipment of the educational process (approved. Ministry of Education of Russia 08.04.2014)

[13] 13.Claudia Flowers, David W. Test, Tiana C. Povenmire-Kirk, Karen M. Diegelmann, Kimberly R. Bunch-Crump, Amy Kemp-Inman, Crystalyn I. Goodnight, «A Demonstration model of interagency collaboration for students with disabilities: a multilevel approach». The Journal of Special Education, vol. 51, Issue 4, 2017, pp. 211-221.

[14] 14.Ibis Marlene Álvarez Valdivia, Iosbel González Montoto, «Teachers' intercultural competence: a requirement or an option in a culturally diverse classroom?». International Journal of Inclusive Education, vol. 21, 2017, pp. 510-526.

[15] 15.Johny R. Daniel, North Cooc, «Teachers' perceptions of academic intrinsic motivation for students with disabilities». The Journal of Special Education, vol. 53, 2018, pp.68-93.

[16] 16.Diana Dias, Diana Soares, «Civic learning outcomes: a step towards an inclusive higher education». International Journal of Inclusive Education, vol. 21, 2017, pp. 360-374.

[17] 17.Letter of the Ministry of education of Russia from June 1, 2017 No. LO - 1164/05 "About the changes of legal regulation of admission to training on bachelor, programs, specialist degrees and podgotovitelno branch" // LRS «Consultant Plus».

[18] 18. Order of the Ministry of education of Russia of June 11, 2014 N 657 "On approval of the methodology for calculating indicators of monitoring of the education system".

[19] 19.Order of the Ministry of education of the Kaluga region of March 31, $2014 \mathrm{~N} 643$ "On approval of Requirements for the organization of educational process for training of disabled people and persons with disabilities in professional educational institutions of the Kaluga region".

[20] 20.Tatyana A. Naumova, Nadezhda I. Vytovtova, Nicholas W. Mitiukov, Teymur E. Zulfugarzade, «Model of distant learning educational methods for the students with disabilities». European Journal of Contemporary Education, 2017, 6(3): 565-573.

[21] 21.Order of the Ministry of labor of Russia of 17.12.2015 No. 1024n " On classifications and criteria used in the implementation of medical and social examination of citizens by Federal state institutions of medical and social examination". 